\section{Comparative Growth and Development of Nerine bowdenii W. Watson: Bulbs in Situ versus Replanted}

\author{
Karen I. Theron and Gerard Jacobs \\ Department of Horticultural Science, University of Stellenbosch, Private Bag \\ X5018, 7599 Stellenbosch, South Africa
}

Additional index words. cut flower, dry weight changes, reserves, sink and source, Amaryllidaceae

\begin{abstract}
Flowering-size Nerine bowdenii bulbs were sampled from a commercial planting at 2-week intervals from 13 Aug. 1991 to 14 June 1992. They were dissected, and the following variables were recorded: 1 ) number and dry weight of fully sheathing leaf bases or leaves of each growth unit, 2) length and dry weight of foliage leaves, 3) fresh weight of outermost inflorescence, and 4) dry weight of daughter bulbs. Bulb organs that served as sinks and sources changed as the bulb progressed in its growth and developmental cycle. Before the new foliage provided photosynthates, growth depended on reserves deposited and stored in leaf bases during the preceding seasons. Reserves were used for the development of new leaves (foliage and bases), roots, and daughter bulb enlargement. Once the foliage became the photosynthate source, reserves were stored in old and new leaf bases. The inflorescence became the major sink when elongation of the scape initiated. Thereafter, daughter bulbs became the dominant sinks, receiving photosynthates from the senescence foliage and the reserves stored in leaf bases. The decrease in dry weight of the leaf bases was prominent in bulbs that remained in situ.
\end{abstract}

Nerine bowdenii is a fall-flowering, synanthous, perennial bulbous plant indigenous to southern Africa (Du Plessis and Duncan, 1989). The species grows in regions with summer rainfall and cool, dry winters. The foliage emerges in spring and achieves senescence after anthesis in the fall (Rees, 1985; Van Brenk and Benschop, 1993). The scape bears an umbel-like compound inflorescence consisting of helicoid cymes (Dalgren et al., 1985). It is an important cut flower, but low flowering percentages limit its share of the Dutch cut-flower market (Berghoef and Van Brenk, 1983). According to Rees (1985), inflorescence initiation occurs regularly in bulbs with a circumference of 12 to $14 \mathrm{~cm}$. However, many inflorescences do not elongate and become desiccated, thus not flowering. Several factors responsible for nonflowering have been reported; these include 1) unfavorable storage conditions (Sytsema, 1971; Van Leeuwen, 1988), 2) underdeveloped inflorescences (Van Brenk, 1988), 3) unfavorable growing conditions (Berghoef and Van Brenk, 1983; Bost, 1985), and 4) bulb circumferences <12 cm (Bost, 1985; Rees, 1985).

Received for publication 17 Dec. 1994. Accepted for publication 11 May 1994. We wish to thank A. Doorduin and S. Oudhuis (Oak Valley Flowers) for facilities, plant material, and supervision, and S.A. le Grange for editorial assistance. The cost of publishing this paper was defrayed in part by the payment of page charges. Under postal regulations, this paper therefore must be hereby marked advertisement solely to indicate this fact.
In South Africa, $N$. bowdenii is grown commercially in regions with climates different from its natural habitat and under conditions different from those it is grown under in Europe (Van Brenk and Benschop, 1993). Bulbs are stored at $2 \mathrm{C}$ for 3 months before being planted in the last week in September. Bulbs are then left in situ for two growing seasons, after which they are lifted, cleaned, and again stored at $2 \mathrm{C}$ from the first week in July. Bulbs left in situ during winter flower earlier than replanted bulbs (Theron and Jacobs, 1994). Commercial harvesting periods for cut flowers, therefore, are extended when replanted and in situ bulbs are used.

Our purpose was two-fold: first, to compare the growth and development of replanted bulbs with bulbs left in situ and, second, to determine the seasonal changes in dry or fresh weight of various bulb components.

\section{Materials and Methods}

Plant material. Bulbs from a commercial $N$. bowdenii planting were used. They were grown in a $64 \%$ shadehouse in the Elgin region of the Western Cape, South Africa (lat. $\left.33^{\circ} 54^{\prime} \mathrm{S}\right)$. The climate is Mediterranean with cool, wet winters and dry, hot summers. The average annual rainfall is $\approx 1000 \mathrm{~mm}$ (Dept. of Agriculture and Water Supply, 1989). Bulbs (12 to $14 \mathrm{~cm}$ in circumference) were planted at a density of $160 \mathrm{bulbs} / \mathrm{m}^{2}$. Bulbs were irrigated and fertilized, and pest control was applied according to commercial practices. The light intensity in the shadehouse, recorded at 1100 HR on a sunny day in midsummer, was 440 $\mu \mathrm{mol} \cdot \mathrm{m}^{-2} \cdot \mathrm{s}^{-1}$. Bulbs left in situ during the preceding winter were planted on 1 Oct. 1990, while the replanted bulbs were set on 26 Sept. 1991 after being in cold storage at $2 \mathrm{C}$ from 1 July 1991.

Terminology. Nerine bowdenii bulbs are composed of a series of growth units (Van Brenk and Benschop, 1993). A growth unit undergoes a vegetative phase, during which leaves are formed, followed by a reproductive phase during which the apex is transformed into an inflorescence. At anthesis, in the fall, at least three growth units are evident in a flowering-size bulb (Theron and Jacobs, 1994). The oldest growth unit consists of the currentseason's inflorescence $(\mathrm{N})$, which is subtended by leaf bases. In some bulbs, leaf bases from the preceding growth unit $(\mathrm{N}-1)$ also are present. Two to three daughter bulbs are present in the axils of the oldest leaf bases. The second growth unit is composed of a developing inflorescence $(\mathrm{N}+1)$, which reaches anthesis in the next fall. It is subtended by fully expanded leaves that senesced during the winter. Developing inflorescence $\mathrm{N}+2$ is subtended by young unexpanded leaves and constitutes the third growth unit. The leaves of growth unit $\mathrm{N}$ +2 will expand after winter, whereas the inflorescence $\mathrm{N}+2$ reaches anthesis in the second fall. Two to three leaf primordia develop in the fourth growth unit $(\mathrm{N}+3)$, and the apex is vegetative (Theron and Jacobs, 1994).

Data recorded. At 2-week intervals, from 13 Aug. 1991 to 14 June 1992, 10 bulbs were sampled at random from the outdoor plantings or the $2 \mathrm{C}$ cold store and brought to our laboratory. Bulbs were dissected and the following variables were recorded: 1) number and dry weight of fully sheathing leaf bases $(\mathrm{N}-1, \mathrm{~N}$, $\mathrm{N}+1), 2$ ) length and dry weight of expanding foliage $(\mathrm{N}+1), 3)$ fresh weight of inflorescence $\mathrm{N}$, and 4) dry weight of dependent daughter bulbs (those without their own roots and foliage). Dry weight was determined after lyophilizing the fresh samples.

\section{Results}

General growth and development. Bulbs lifted in winter and stored at $2 \mathrm{C}$ for 3 months before replanting in early October flowered $\approx 4$ weeks later (Fig. 1) than bulbs left in situ (Fig. 2). Flowering extended over 4 weeks in both plantings. During the early stages of the leafless phase (foliage not emerged), the longest of the new developing leaves were $\approx 50 \mathrm{~mm}$ long. This remained more or less unchanged for bulbs in cold storage; however, leaves of bulbs left in situ continued to grow because the winter soil temperatures (minimum 9C) in Elgin are not low enough to inhibit development (data not presented). Leaf emergence (when leaves are $\approx 100 \mathrm{~mm}$ long) in bulbs left in situ occurred $\approx 2$ months earlier than in replanted cold-stored bulbs. The maximum foliage length in replanted bulbs was $500 \mathrm{~mm}$ and that of bulbs left in situ was $600 \mathrm{~mm}$. The period from emergence until senescence of foliage was similar in the two plantings (Figs. 1 and 2). We observed new growth on the perennial, branched root system (Rees, 1985) in both spring plantings shortly after emergence of the foliage above the soil. 
Dry weight changes in bulb components. The total dry weight of bulbs left in situ during the preceding winter decreased until 24 Sept. 1991 (spring); thereafter, it increased. At the same time, the longest foliage leaf reached $50 \%$ of its final length. The decrease in total dry weight was due to a decrease in the dry weight of the $\mathrm{N}-1$ and $\mathrm{N}$ leaf bases, similar to the decrease in dry weight in mother bulb scales of Lilium longiflorum Thunb. (Miller and Langhans, 1989). Only the $\mathrm{N}+1$ foliage gained dry weight during this period because
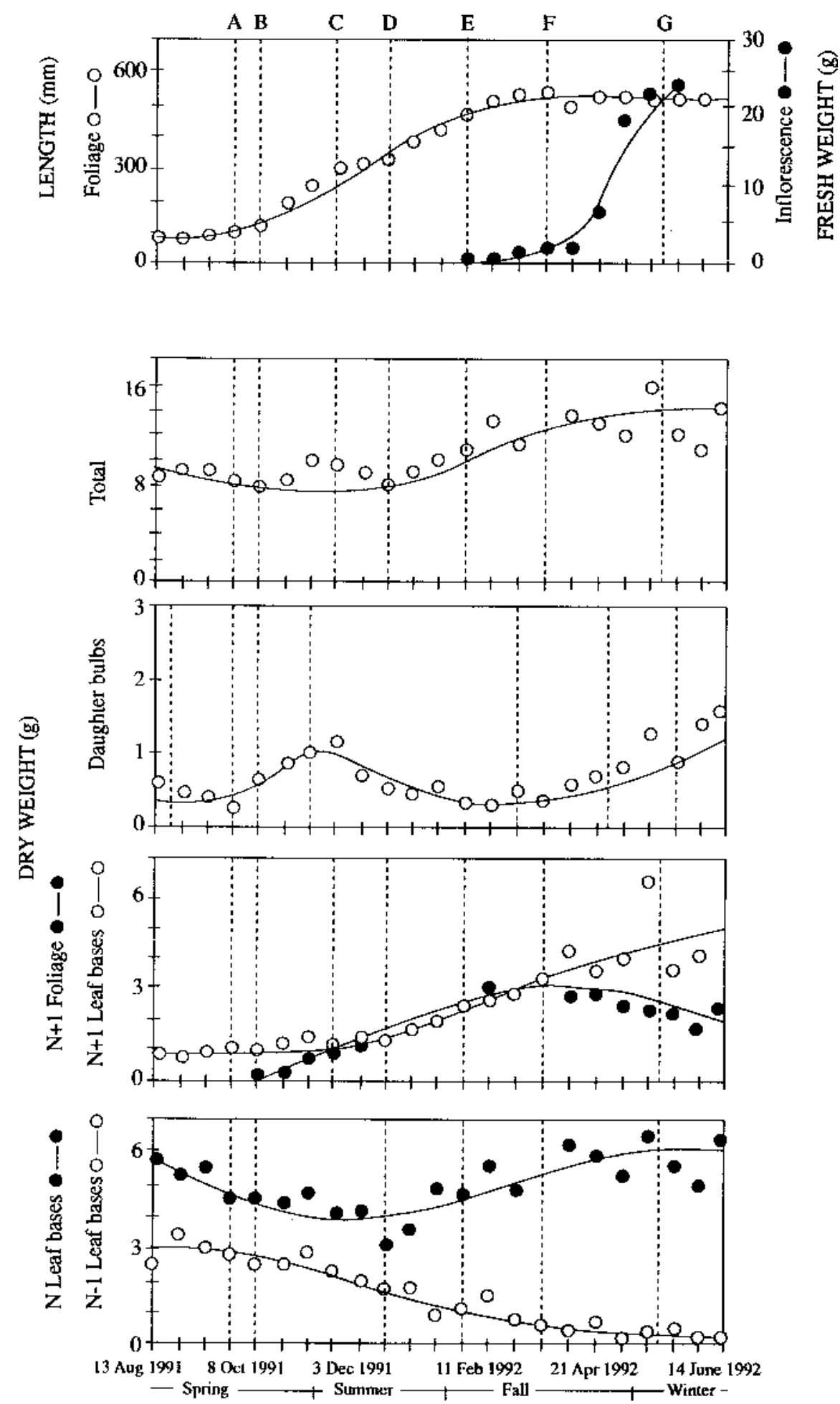

SAMPLING DATE

Fig. 1. Changes in dry weights of various growth units and components of Nerine bowdenii over a growing season in relation to foliage and inflorescence development. Bulbs were in cold storage at $2 \mathrm{C}$ during the preceding winter. (A) Planting date (26 Sept. 1991), (B) leaf emergence, (C) longest leaf 50\% of final length (19 Nov. 1991), (D) longest leaf 60\% of final length (17 Dec. 1991), (E) end of foliage elongation (29 Jan. 1992), (F) start of scape elongation (11 Mar. 1992), and (G) anthesis of first inflorescence.

the longest leaf grew $\approx 200 \mathrm{~mm}$ longer (i.e., 100 to $300 \mathrm{~mm}$ ). During this period, the dry weight of dependent daughter bulbs decreased because the daughter bulbs became independent of the mother bulb as they increased in size. Therefore, they subsequently were not sampled with the mother bulb. The decrease in total dry weight was attributed to the growth of daughter bulbs, root growth, and respiratory losses (Fig. 2).

The initial increase in the total dry weight of bulbs was due to an increase in dry weight of the $\mathrm{N}+1$ foliage. None of the other bulb components increased in dry weight until 8 Oct. 1991. At this time, the longest foliage leaf reached $60 \%$ of its final length, and the $\mathrm{N}$ leaf bases started increasing in dry weight. The $\mathrm{N}$ +1 foliage, therefore, started to export photosynthates to the N leaf bases. On 5 Nov. 1991, when the longest foliage leaf reached its final length, the $\mathrm{N}+1$ foliage reached a plateau in dry weight, and the $\mathrm{N}+1$ leaf bases increased in dry weight. From 13 Aug. until 8 Oct. 1991, the $\mathrm{N}$ and $\mathrm{N}-1$ leaf bases were the sources of reserves. Thereafter, the $\mathrm{N}+1$ foliage became the main source of photosynthates (Fig. 2).

The $\mathrm{N}+1$ foliage produced no further increase in dry weight after 5 Nov. 1991. This result indicates that, except for the respiratory requirements of foliage, it exported all photosynthates. The total dry weight of the bulbs reached a maximum on $11 \mathrm{Feb} .1992$, concurrently with the maximum level reached in the $\mathrm{N}+1$ leaf bases. The maximum for $\mathrm{N}$ leaf bases followed thereafter. The dry weight of the $\mathrm{N}+1$ leaf bases remained at the elevated level for the remainder of the growing season. There was, however, a decrease in the dry weight of the $\mathrm{N}$ leaf bases that coincided with an increase in dry weight of the new generation of daughter bulbs. Elongation of inflorescence $\mathrm{N}$ started when the $\mathrm{N}+1$ leaf bases reached maximum dry weight. Because the dry weight of the $\mathrm{N}$ and $\mathrm{N}+1$ leaf bases remained unchanged during the rapid growth phase of inflorescence $\mathrm{N}$, we conclude that the current photosynthate from the $\mathrm{N}+1$ foliage is the source of energy for this development. After anthesis, the dry weight of the $\mathrm{N}+1$ foliage decreased as leaf senescence started (Fig. 2).

During storage at $2 \mathrm{C}$, the dry weight of the bulbs did not change (Fig. 1). The total dry weight decreased between the planting of the bulbs on 26 Sept. and 19 Nov. 1991, when the longest foliage leaf had reached $50 \%$ of its final length. This loss in dry weight was due to a decrease in the dry weight of the $\mathrm{N}$ and $\mathrm{N}-1$ leaf bases, which in turn was the result of reserves being used for respiration in the bulb and the development of daughter bulbs and roots. The dry weight of the $\mathrm{N}+1$ foliage increased first. When the $\mathrm{N}+1$ foliage started to produce excess photosynthates, the dry weight of the $\mathrm{N}$ and $\mathrm{N}+1$ leaf bases and total bulb weight increased, which was when the longest foliage leaf reached $60 \%$ of its final length (Fig. 1). Daughter bulbs depended on reserves from the $\mathrm{N}-1$ and $\mathrm{N}$ leaf bases until 3 Dec. 1991. The increase in total dry weight 
continued, due to the increase in the dry weights of the $\mathrm{N}$ and $\mathrm{N}+1$ leaf bases and the $\mathrm{N}+1$ foliage. The dry weight reached a plateau when inflorescence $\mathrm{N}$ initiated rapid growth on 25 Mar. 1992. During this period of growth, the dry weight of the $\mathrm{N}+1$ foliage started to decrease. This decrease also occurred in total bulb dry weight but only after anthesis. During elongation of inflorescence $\mathrm{N}$, the dry weight of the $\mathrm{N}$ and $\mathrm{N}+1$ leaf bases did not decrease, which indicates that photosynthates from the $\mathrm{N}+1$ foliage supported inflorescence growth. The second generation of daughter bulbs increased in dry weight starting in early Feb.
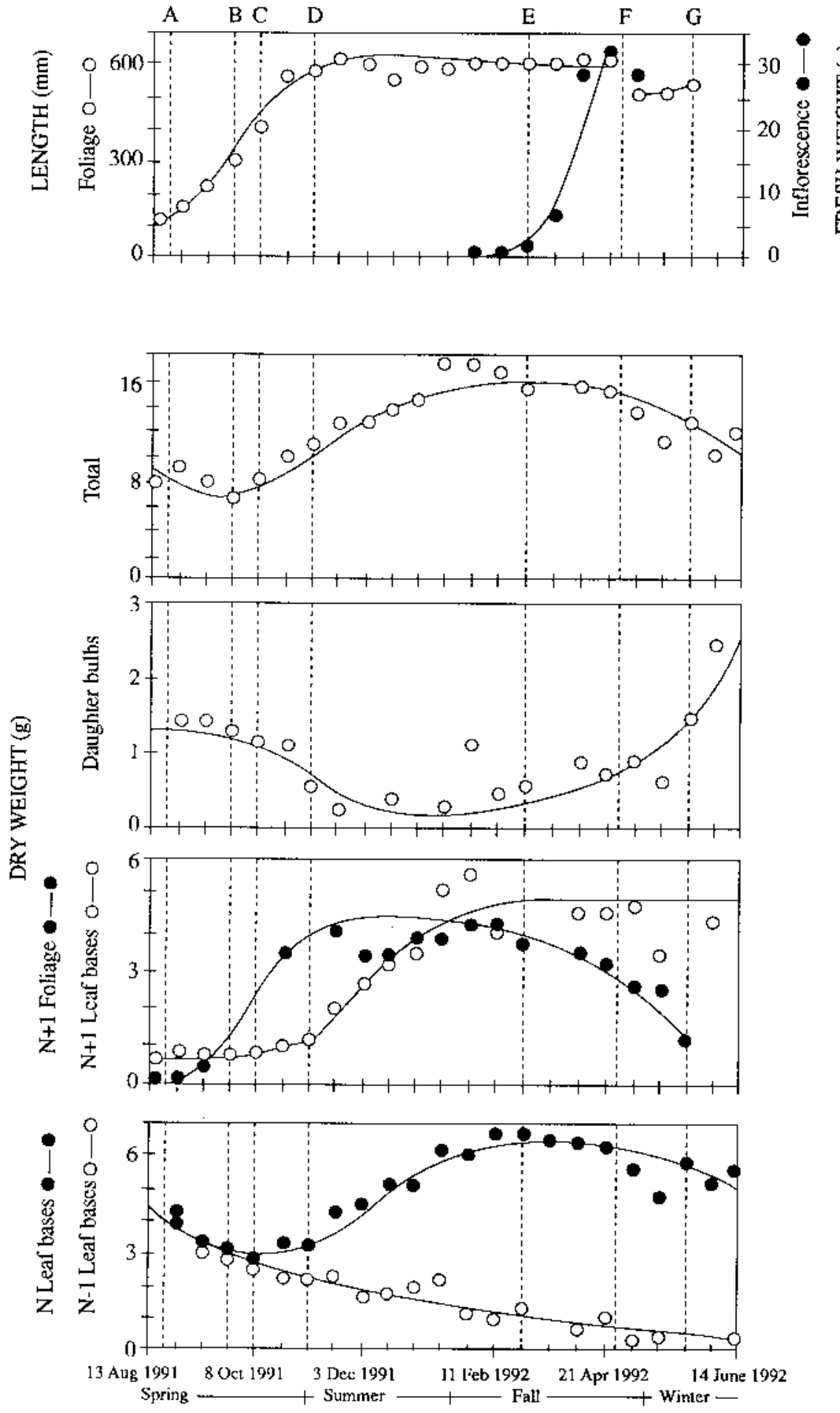

SAMPLING DATE

Fig. 2. Changes in dry weight of different growth units and components of Nerine bowdenii over a growing season in relation to foliage and inflorescence development. Bulbs remained in situ during the preceding winter. (A) Leaf emergence, (B) longest leaf 50\% of final length (24 Sept. 1991), (C) longest leaf 60\% of final length (8 Oct. 1991), (D) end of foliage elongation (5 Nov. 1991), (E) start of scape elongation (25 Feb. 1992), (F) anthesis of first inflorescence, and (G) senescent foliage.

1992. After anthesis, they became dependent on reserves from $\mathrm{N}$ leaf bases, as depicted by the decrease in the dry weight of the bases (Fig. 1). Toward the end of the growing season, the total dry weight of the replanted bulbs decreased, but not to the same extent as in bulbs left in situ. The foliage of replanted bulbs (Fig. 1) remained functional longer after anthesis than did the foliage of bulbs that remained in situ (Fig. 2). Therefore, the total dry weight of the replanted bulbs decreased less than that in bulbs that remained in situ (Figs. 1 and 2).

\section{Discussion}

Bulb organs serving as sinks and sources changed through the season as the growth and development of $N$. bowdenii changed (Figs. 1 and 2). During the early part of the growing season, until the new foliage supplied the bulb with photosynthates, growth depended on reserves stored in $\mathrm{N}-1$ and $\mathrm{N}$ leaf bases. The sinks active in the bulb during this period were $\mathrm{N}$ and $\mathrm{N}+1$ inflorescences, the vegetative phase of growth unit $\mathrm{N}+2$, root and daughter bulbs, and expansion of the $\mathrm{N}+1$ leaves. In terms of sink size, the latter three were the dominant sinks. Once the foliage became the source, photosynthates were stored in $\mathrm{N}$ and $\mathrm{N}$ +1 leaf bases, and due to their size, they became the dominant sinks in the bulb (root growth was not taken into account). During this time, the following smaller sinks were also active in the bulb: 1) inflorescence $\mathrm{N}$, as individual florets advanced to stage Late $\mathrm{G}$ [carpels fused and elongated (Theron and Jacobs, 1994)], 2) N + 1 inflorescence, which was in the floret initiation phase, and 3) the vegetative phase of growth unit $\mathrm{N}+2$, initiating leaf primordia (Theron and Jacobs, 1994). Once it started to elongate, inflorescence $\mathrm{N}$ became the major sink. Subsequently, the new generation of daughter bulbs became the dominant sinks. They received photosynthates from the senescing foliage and from reserves stored in $\mathrm{N}$ leaf bases.

Bulb quality, in terms of circumference size and dry matter status, is important for the commercial flower grower. The initial growth phases depend on reserves stored during the preceding season. Optimum growing conditions are equally important because foliage development must not be impeded. Factors that negatively affect photosynthesis, for example, low light intensity, high planting densities, water stress, and high temperatures, should be avoided. Although bulbs can use a part of the reserves in $\mathrm{N}-1$ and $\mathrm{N}$ leaf bases, a limited photosynthate supply will result in the abortion of inflorescence $\mathrm{N}$ and retarded development of inflorescence $\mathrm{N}+1$. Therefore, if producers want to obtain two flowering periods, both systems can be used, but then after a season in situ, bulbs have to be lifted to thin plants or the shading due to overcrowding by new daughter bulbs will cause problems. Also, the reserve status, in terms of total dry weight, is lower after a season in situ, but this will be rectified by starting with replanted bulbs in the following spring. 


\section{Literature Cited}

Berghoef, J. and G. Van Brenk. 1983. Effect of temperature on flowering of Nerine bowdenii W. Watts [sic]. Acta Hort. 134:41-48.

Bost, L. 1985. Jaarrond project Nerine: Betere bloeiresultaten bij tweede teelt. Vakblad voor de Bloemisterij 36:32-36.

Dalgren, R.M.T., M.T. Clifford, and P.F. Yeo. 1985. The families of the monocotyledons. SpringerVerlag, Berlin.

Dept. of Agriculture and Water Supply. 1989. Climatic statistics for the winter rainfall region. Section Agrometeorology, Elsenburg, Republic of South Africa.
Du Plessis, N. and G. Duncan. 1989. Bilbous plants of Southern Africa-A guide to their cultivation and propagation. Tafelberg Publishers, Cape Town, South Africa.

Miller, W.B. and R.W. Langhans. 1989. Reduced irradiance affects dry weight partitioning in Easter lily. J. Amer. Soc. Hort. Sci. 114:306309.

Rees, A.R. 1985. Nerine, p. 297-299. In: A.H Halevy (ed.). CRC handbook of flowering. vol. 1. CRC Press, Boca Raton, Fla.

Sytsema, W. 1971. Effect of storage and date of planting on flowering and bulb growth of Nerine bowdenii. Acta Hort. 23:99-105.

Theron, K.I. and G. Jacobs. 1994. Periodicity of inflorescence initiation and development in Nerine bowdenii W. Watson (Amaryllidaceae). J. Amer. Soc. Hort. Sci. 119:1121-1126.

Van Brenk, G. 1988. Opbouw van de bol, groei en bloei, p.16-21. In: Teelt van Nerine. Bloementeeltinformatie no. 21. Proefstation voor de bloemisterij te Aalsmeer, The Netherlands.

Van Brenk, G. and M. Benschop. 1993. Nerine, p. 559-588. In: A. de Hertogh and M. le Nard (eds.). The physiology of flower bulbs. Elsevier, Amsterdam.

Van Leeuwen, P. 1988. Oogst en verwerking van de bollen, p. 32-33. In: Teelt van Nerine. Bloementeeltinformatie 21. Proefstation voor de bloemisterij te Aalsmeer, The Netherlands. 